\title{
“NO OPPORTUNITY FOR SONG:” A SLOVAK IMMIGRANT'S SILENCING ANALYZED THROUGH HER PRONOUN CHOICE
}

\author{
Danusha V. Goska \\ William Paterson University
}

"[In Slovakia], A field of agricultural laborers would sing folk songs together as they worked, songs in a minor key, breathing in patience and resignation. [In American factories there is] no opportunity for song" (Ledbetter 1918, 30-31).

\section{Introduction}

I can't tell the most frightening story I know, because stories are made of words, and once I was without them. I was trekking in Nepal and ended up with amnesia. Later I stumbled into a mission hospital with a bruised jaw. A bad fall? I can't say. I had no words. No words for this thing that was wrenching and crying, in which " $I$ " - a bundle of terror - seemed trapped. No words for where I began, stopped, or the mud stubble terrace on which I sat. No words to map, no words to define, no words to possess. No words for the blobs of light and shadow shifting or parking before me. No words to rank or relate the garbage - my own memories - blasting against my consciousness, randomly, insistently. Names shouted inside my head - my family, my lover, my own name; places - my hometown in America, the name of the mission hospital I'd 
eventually find my way to. An eleven-thousand foot mountain rose in front of me. A backpack pulled at my shoulders. A Nepali woman stroked my arm. I had no words to weave any of these into a safety net of story or meaning. All were uncontrollable, unpredictable, stimuli, which somehow, suddenly, had complete, and therefore sinister, power, and struck again and again against - some other thing - me - a thing I couldn't name or inhabit, for I had no words. I remember this sensation now when I want to know what it must have been like for my immigrant mother when, as an eight-year-old Slovak peasant child, she first arrived in America in 1929.

A child of Slavic immigrants, I feel my parents' wordlessness in relation to the dominant culture of which l a m a part, and my own wordlessness in relation to them. Wordlessness is not something that can be fixed with a bilingual dictionary. "Pies" is replaced by "dog"; "macka" by "cat." An ancient peasant culture is replaced by weekdays in the factory and Saturday night bowling. Because that sometimes works we might be foolish enough to imagine that the process can be carried on, finitely, until all the blank spaces are filled in, but this is not so. As soon as the marginalized immigrant catches up, the dominant culture shifts. And there will always be an accent.

In some of my earliest memories I am watching TV with my parents. I hear the broadcasts of the dominant culture into our home as a line of verbal pickets. I can pick out which ones my parents can vault into community, on which they fall impaled - they had thought they understood, and did not - which bar their way completely. It isn't a question of isolated words, or at least not many. My parents were compulsive readers and had better English grammar and vocabularies than most Americans. It's a question of more complex translations. "This is beautiful; this is worthy of note; this is a satisfying complication, climax, dénouement; this reference weaves about us a net of common memory, shared community. Unlocking the key of this word includes you in." Lacking that key, having it and choosing not to use it, is the cultural equivalent of: "Whites Only;" "No Irish Need Apply;" "Christian Establishment." Networks of untranslatable words kept my parents - two very bright people, for whom working two jobs was a matter of course - cleaning rich women's houses, and carrying rich men's bags, for all of their days. 
There is a taste never quite expunged from my tongue, the unique taste of mak - ground poppy seeds boiled with milk and sugar into a dirt-like, thick and pungent paste. Craving this taste and never finding satisfaction for it in any other cultural recipe reminds me that silence works both ways. My parents have something, something with which they infected me, that I feel when I listen to folk songs, that I feel when I grow angry in politically correct debates, that I feel when I look back and see what I've endured, that I as an American can't fully possess. I can't name it; the needed words have been sacrificed.

I grew up in a vacuum of words about my own family. Half ghosts passed before me like costumed actors on a stage; I could not inquire anything of these legendary heroes in babushkas and suspenders. I didn't speak Slovak or Polish; they didn't speak English. As if a cowed but reverential tourist witnessing the drama of an extinct tribe, I had to make do by interpreting alien signs and gestures. As if on a schedule of mystery or spite, they all died before I would learn to converse in their tongues. I went to libraries and bookstores and schoolteachers and could find no knowledge of Poles like my father or Slovaks like my mother, and no history, folk or high art books that even listed "Slovak" or "Slovakia" in their indices. Now myself a professor, my colleagues have no idea who I am, insisting on categorizing me as "white," or, for those with special awareness of socioeconomic nuance, "poor white trash" (Goska 2002).

This paper is part of a continuing effort to beat back the terror of wordlessness. It explores the necessity for, and the creation and maintenance of, the silence experienced by many Slavic immigrants and their descendents. This silence takes many forms, but it can be summed up as a lack of knowledge of, and a sense of taboo and mystery surrounding, one's immediate ancestors and their natal cultures.

Domestic silence is paralleled in the wider culture. Accurate representations of Slavic immigrants are rarely taught in classrooms, represented in high or popular culture, or funded in academia (Wtulich 1994). Scholar and author Michael Novak has reached the highest levels of success in American academe. For all that, he is still a Slovak-American who suffers from this silence. It was "amazing," he said, to realize that he had become an educated, successful adult, without knowing "what my family suffered, 
endured, learned, and hoped" (Novak 1971, 54). Thanks to his American education, any such reflections had been "heretofore shepherded out of sight" (Novak 1971, 53). He has had to endure uncomfortable moments with well-meaning but condescending interlocutors, and been unable to find the right way to respond to them, "No available public standpoint works for me" (Novak 1971, 51). "The silence," he said, "burns like hidden coals in the chest" (Novak 1971, 53).

This paper uses, significantly, as data, an interview recorded on audiotape in 1990 with my mother, Pauline Goska, née Pavlina Kerekova. Mrs. Goska was born in Kovarce, Slovakia, in 1921, to a Catholic, peasant family. She immigrated to the United States in 1929 with her mother and brother. The family was reunited with Mrs. Goska's father, a coal miner, in Pennsylvania. He had been in America since 1920. These dates, her father's occupation, and her birthplace make Mrs. Goska and her family typical members of the epic exodus, dubbed the "New Immigration," which took place between c. 1880 and 1929.

This paper will argue that two factors experienced by Mrs. Goska, one more personal and microcosmic, the other more political and macrocosmic, but both intertwined, necessitated creation of the silence seen as typical of Slavic New Immigrants and their descendents. These two factors are Mrs. Goska's personal deracination and the American racism she and others like her faced on entry in the United States. This paper implies that Mrs. Goska's experience of these two factors is perhaps exemplary of a process undergone by millions of others like her.

\section{Brief Overview of Slovak Immigration, c. 1880-1929}

One historian claims that Slovaks called themselves the "step-children of fortune" (Ledbetter 1918, 5). Slovakia has been invaded and/or occupied by the Turkish, Austro-Hungarian, Nazi, and Soviet empires. Since much of Slovakia is rocky and mountainous, Slovaks have had to work hard to win even a subsistence level of calories from their soil. Poverty can be measured in various ways; in Slovakia it might be described thus: good soil, that near rivers or in valleys, belonged to foreign lords. Slovaks cultivated high, narrow strips of land to which they had to carry manure and/or topsoil (Ledbetter 1918, 6). Children might suffer punishment if they relieved themselves where it would not 
serve to fertilize the family's crops (Stein 1980, 54-55). A rich peasant might own twelve acres of land, not together but in strips, often miles apart; a "poor" peasant might have only an acre. One sixth of the population was landless (Ledbetter 1918, 6; Stein 1980, 92). Slovaks grew what they ate: potatoes, cabbage, turnips, wheat and flour products, and fruits in season. Meat was rarely consumed (Ledbetter 1918, 6-7). During serfdom, officially abolished in the Austrian empire only as late as 1848 but still in practice much later, Slovaks owed fifty percent of their crops to Hungarian lords (Stein 1980, 89). A Slovak immigrant might have handled money but twice a year, or not at all (Ledbetter 1918, 6; Stein 1980, 89).

Some historians went so far as to say that Slovaks are a people without history (Stasko 1974, 20-22); in a sense, this is true. Most Slovaks were, for much of their history, oral, as opposed to literate, peasants. Their rulers were not inspired to produce written works reflective of their lives. In fact, it has been said that the Hungarians, who ruled over Slovakia directly previous to the birth of the informant for this paper, regarded the Slovaks as nonhuman (Stein 1980, 80). In America, the Slovak experience has not inspired even so much as accurate record keeping; no one can say, for example, exactly how many Slovaks arrived in America, when or what they did for a living. (Hammerova 1994, 21; Stein 1980, 81; 109-110). In the academic world, Slavic studies do not have relatively high prestige or funding (Wtulich 1994, 1); even within this marginalized realm, Slovaks are remarkable for their relative invisibility. In a highly praised recent work devoted to the narratives of female immigrants from Eastern Europe, Slovaks are not mentioned (Zaborowska 1995).

Slovaks have few world-famous authors, politicians, or artists to claim as their own. Writers on Slovaks and their history have chosen to concentrate on folk culture, the culture of primarily oral, Christian agriculturists. One effort to introduce the reader to Slovak culture mentions not museums or kings, but prayers and earth: "breviaries contained prayers for entreating the Lord throughout the year for changes in the climate that would improve the year's harvest, help the animals, or otherwise benefit the community" (Alexander 1987: 5). Daily life included survivals of pagan times. For example, "during the Christmas Season, Slovaks followed various rituals that supposedly revealed future spouses, 
chased away witches, or foretold whether joy or sorrow would befall a family or village during the upcoming year" (Alexander 1987: 5-6).

Before 1918, there were no secondary schools in Slovakia. Slovaks, at their own expense, built three; they were "dissolved" by Hungarian rulers (Stasko 1974:26). In the early part of the twentieth century, a peasant had the option of sending his children to school for four winters. He would have to be able to spare the child's labor, and such a peasant was rare. "Children have to work from an early age, usually from about six years of age, and they do work which we would consider not only cruel, but impossible..." (Ledbetter 1918: 7). Before World War I, Slovak children had to study in Hungarian. Schools were staffed with spies whose job it was to ensure that children spoke Hungarian at all times. Belongings were searched to ensure that the child had no written material, including handwritten, in his native tongue. Such experiences made many Slovaks uncomfortable with formal education (Ledbetter 1918:7).

The Austro-Hungarian army, like the schools, was, for Slovaks, also a source of ugly experiences. For example, "A favorite punishment is to hang him [an ethnic minority soldier] up by a sort of harness under the arms, drawn up so that his toes barely touch the ground. He will be kept so until he grows black, then taken down, revived with a bucket of water, and hung up again. Many commit suicide under these punishments" (Ledbetter $1918,8)$. The position of Slav minorities in the Austro-Hungarian army was recorded in Jaroslav Hasek's classic comic novel The Cood Soldier Svejk. In it, a Czech soldier manages to survive by presenting the appearance of idiocy while not cooperating with the agenda of his superiors.

The official liberation of the serfs in 1848 was not much of an immediate historical boon to the Slovaks, as it deprived them of their traditional means of livelihood (Stein 1980:90). A population of physically strong laborers was freed up. America needed such workers; her industry was expanding. American industrial recruiters traveled to Slovakia and other lands in Eastern and Southern Europe in order to advertise a country where streets were paved with gold (Stolarik 1985, 21; Alexander 1987, 7; Ference 1995, 34). During the New Immigration, historians estimate that twenty-five percent of all Slovaks in the world lived in the 
United States, making them the largest, per capita, of the New Immigrant groups to emigrate (Ledbetter 1918, 10; Stein 1980, 92; Stasko 1974, 34). Sixty-eight percent of Slovak immigrants, it is estimated, were agriculturists; in America, ninety percent found employment in industry (Ference 1995, 35). Slovaks soon became a significant percentage of workers in America's steel mills, oil industry, coalmines, meat packing plants, cigar industry, and of her domestic servants. An historian in 1918 wrote:

Wherever they have settled in this country, the Slovaks have undertaken the hard, heavy labor, the work fundamental to our great industries. Owing to their lack of previous opportunity, they have always had to fall into the ranks of the unskilled, where their dogged industry and perseverance have made them valuable, and their uncomplaining submissiveness has sometimes made them the subjects of exploitation (Ledbetter 1918, 11).

Slovaks and other New Immigrants were often paid less than native-born Americans, white or black, (Wtulich 1994:94), and they earned, on average, less money than it would have taken to support a modest-sized family of four (Stolarik 115; 112-113). This necessitated child labor, and the taking in of boarders who had to sleep in shifts.

Some Slovaks attempted to improve their fatethrough fraternal societies. These societies recorded Slovak hunger for education. For example, the first Slovak-American fraternal society stated as its first goal: "To educate Slovak immigrants" (Ledbetter 1918: 17). Other societies followed suit. Many expressed poignantly contrary goals: to foster the Slovak language, and to help to Americanize new immigrants. The mutual aid that these groups offered to each other, some financial, was credited with keeping Slovaks off the welfare rolls (Ledbetter 1918:20).

Fraternal organizations promised the support a village used to provide. New Immigrant workers died young, often, and violently (Wtulich 1994:83-84; Bukowczyk 1987:26-27). In the village it would be unheard of for a Slovak to go to his grave without a proper funeral. In America it was all too much a possibility. "Do you think that on this foreign soil anyone besides your close family and the undertaker would come to your funeral if you did not belong to a fraternal society?" one asked (Alexander 1987:19). Regulations required that "all members, properly adorned with 
the association's funeral badge, had to march in a fellow lodge member's funeral" (Alexander 1987: 25).

One historian has argued that this kind of formal organization for mutual help didnot come easily to Slovaks (Alexander 1987:21). Slovaks, one Slovak said, "...have no conception of mutual aid societies" (Alexander 1987:18). This political ignorance could be related in part, at least, to Hungarian oppression. "By the early 1880 's, the Hungarian government had effectively banned all Slovak organizations as part of its Magyarization program" (Alexander 1987:18). Further, Slovaks themselves were simply not used to formalizing the kind of mutual aid that had always come naturally, and many were kept out of such organizations by membership fees that they could not pay (Alexander 1987:22). Sadly, fraternal societies themselves were not without risk. One was founded by a notorious Slovak wheeler-dealer who squandered thousands of dollars entrusted to him by greenhorn peasant immigrants (Stolarik 1989:119-123).

One might well ask why the Slovaks did the dirty and dangerous industrial labor that they did perform, and for which their backgrounds as peasants did not train them. Why didn't they immigrate to farmlands? In fact, forces more powerful than they shunted them to industrial labor. American officials invented racial categories; the New Immigrants' assigned racial identity determined what work they were suited for (Bukowczyk 1987:21; Wtulich 1994:12). Later, their children often would be tracked into vocational, rather than academic, programs in school (Wtulich 1994:51-67). Many Slovaks, however, did leave the harsh conditions they found in America; in some years, more Slovaks went back to Slovakia than came to the U.S. (Stasko 1974:48).

Slovaks' and other New Immigrants' peasant culture was used as evidence in the invention of racial categories, categories of separate and less desirable races from both white and black native-born Americans (e.g.: Grant 1916, 78; Higham 1967, 133). During congressional debates on the racial nature of the New Immigrants, one congressman focused on the demonstrated racial inferiority of Slovaks as evidenced in their peasant culture:

...their homes are often nothing but scanty huts, of one room, wherein the whole family lives and sleeps promiscuously. The furniture and outfit is very primitive, mostly homemade, and has to last for generations... The 
body clothes of the men are made of coarse linen, their summer clothing of the same material, only coarser, and in winter their clothing consists of suits made from a coarse and thick woolen felting, in the natural color of the wool; an everlasting cap of the sheepskin and a pair of sandals about complete an outfit which has been in vogue with them for generations and which may be an heirloom, since the style hardly ever changes. An important part of their outfit is the roomy and long mantle without sleeves, made up from half a dozen sheepskins which are tanned, the wool being left on... when the men are away from home these mantles form their complete bed. What these patriarchal cloaks may lack in style is generally made up for by some gaudy embroidery or even painting on the leather side of it. I do not wish to be unjust to these people, but from all I can learn their demand for water is but very limited for the use of the outer body as well as the inner. Their diet consists of... offal, or, if times are flush, lungs, liver, or other unpopular but cheap portions of beef. In all, it will be seen that the tastes of these people are anything but refined, are low, in fact...(quoted in Warne 1913:137-138).

In assessing Slovaks as an inferior, non-white race, an American official in Europe stated:

...these Slovaks are not a desirable acquisition for us to make, since they appear to have so many items in common with the Chinese. Like these, they are extremely frugal, the love of whisky of the former being balanced by the opium habit of the latter. Their ambition lacks both in quality and quantity. Thus they will work similarly cheap as the Chinese, and will interfere with a civilized laborer's earning a white laborer's wages (Consul Sterne, quoted in Lodge 1891).

Slovaks knew of their assigned status. Pittsburgh novelist Thomas Bell wrote, "As a small boy I could not understand why I should be ashamed of the fact that I was Slovak. While Irish and German kids could boast of the history of their ancestors, I as a Slovak boy did not know anything about the history of my people" (Bell 1976[1941]: 418). Bell wrote of one Slovak, a fictional character based on his own father, wishing he could 
communicate the humanity of Slovaks to Americans, using Slovak folk culture as the medium of communication.

'We're only Hunkies... Once I had an idea, I thought to myself: If we were to sing some of our songs and explain what they were about - would it surprise them to learn that we sang about such things and had such feelings? If we told them how we lived in the old country, how we worked the land, the crops we grew, the little money we saw from one year's end to another, our holidays and festivals - would they realize that even though we spoke different languages we were still men like themselves, with the same troubles, the same hopes and dreams? I hoped that we might learn to respect one another, that we might even become friends...' (Bell 1976 [1941]: 196).

Efforts to communicate the worth and humanity of the New Immigrants through their folk culture ultimately failed; the times were not sympathetic. Rather, Americans openly expressed fear and contempt. In an article published by the New York Times company, Etta V. Leighton struggled to be liberal and charitable to the New Immigrants; she stopped at valuing their culture. The idea that folk culture was a boon to America was a "curious fallacy" she warned. Any equation of the immigrant's folk culture with American culture made use of a "false scale of values." Valuing the culture of "the European peasant," she wrote, "coming to us unlettered and untaught," "spells peril to America" (Leighton 1922: 115). Kenneth L. Roberts, a popular American novelist on assignment in Europe for the Saturday Evening Post, sent back alarmed and contemptuous dispatches from the homelands of the New Immigrants. The Post ran a derisive caption under a photo of Slovak ceramics (Roberts 1920: 8). Even voices far to the left of the immigration debate, like Franz Boas, who devoted his career to, and groomed his students for, generating an appreciation of African-American culture, did not argue that the New Immigrants brought a worthy culture with them. Boas argued, instead, that America could improve the New Immigrants' racial type by making them more American (Boas 1938; 264; Hyatt 1990: 99).

The feckless few of the majority culture who came to the defense of the Slovaks and others like them during the racial debates of the early part of the twentieth century also used the 
language of racism. These liberals argued that the Slovaks' racial qualities of docility, low intelligence, and great capacity for hard manual labor would help, rather than hurt, America. For example, Eleanor Ledbetter wrote in 1918, in The Slovaks of Cleveland, With Some General Information on the Race:

$\mathrm{He}$ is naturally conservative, and not inclined to seek changes in the social order, therefore he has an extremely small representation among the Socialists, and is never an agitator. Rather his disposition is always to make the best of things as he finds them. He is simple, direct, straightforward. The word subterfuge has no equivalent in his language. He is industrious in a patient, plodding way. In his own country, he worked to an accompaniment of song. A field of agricultural laborers would sing folk songs together as they worked, songs in a minor key, breathing in patience and resignation. Here he is sometimes confused by the speeding up process, but adapts himself to it with the same spirit of patient resignation, but alas, with no opportunity for song (Ledbetter 1918: 30-31).

No grass roots movement, government or academic intervention has eradicated the peasant immigrants' legacy of shame. Artist and author Alvena Seckar (1915-) was a child of Slovak immigrants. Her 1952 children's book, Zuska of the Burning Hills was named one of the New York Times' best books for children that year. Zuska is largely autobiographical. As part of her picture of the life of a Slovak-American child, Seckar depicts the shame that her main character, Zuska, feels for her immigrant parents. Seckar's struggle with her shame helped to inspire her to write books explaining the worth of even "humble" people (Seckar dust jacket).

This shame is not a thing of the past, and it is stronger in Slavic-Americans than in other groups, or so my experiences convince me. I live and teach in and near Paterson, NJ, a majority minority city. Most Americans I encounter identify themselves with hyphens: Italian-Americans, Peruvian-Americans, AfricanAmericans, Lebanese-Americans. Individuals distinguish ethnic allegiance through language, dress, food, worship, customs, social associations and politics. I encounter shame among Slovaks and socioeconomically comparable Slavs that I do not encounter in other immigrant groups. I will offer just one example. In 2002, my sister-in-law reported to me that my niece, Marlee, was doing 
well in her science classes. I sent to Marlee Eve Curie's biography of her mother, the scientist Marie Curie, a Polish woman who won two Nobel Prizes. The book has been a favorite among schoolgirls for generations. Marlee's mother reported that Marlee, an otherwise avid reader, set the book aside, wanting nothing to do with it. Because of media images and pressures at school, my sister-in-law said, "She's ashamed of that whole side of her ancestry." She further reported that Marlee was happily involved in Irish step dancing in school, and preferred to focus on Irish ethnicity as cute and desirable, and preferred to forget her Slavic ancestry as darkly shameful. Marlee had positive contact with her grandmother, who had been born in Slovakia. One set of Marlee's maternal great grandparents, whom she never met, were ScotchIrish.

Anecdotes are, of course, of limited scientific value. A relatively recent ethnography of Slovak-Americans provides data that supports my assertion. Eva Ribcanská reports that "working class status, low level of education, poverty and backwardness" were important ethnic markers for Slovaks (71). Slovaks knew that they were "assigned low social prestige" (71); their strategy in response to this was to lose ethnic markers and to assimilate into the mainstream, by terminating their use of Slovak language, and changing their names, for example (71). "They did not want to be Slovak; they wanted to be American as much as possible," one informant said, in what Ribčanská assessed as a common sentiment among her informants. Other common statements include, "My parents would never acknowledge their ethnicity in public" and "They were ashamed of their ethnic background" (72). One informant reported, "It was not a pleasure to be Slovak" (78).

\section{Hypotheses}

Pressures encountered in immigrating and in daily life in America may have worked against the Slovaks' retention of culture and transmission of it to their children in any coherent form. Slovak immigrants were primarily peasants. This changed drastically and immediately upon arrival in America. Here they worked primarily in heavy industry. Song had played a great role in their daily life; in America, Slovaks worked "with no opportunity for song."

Slovaks faced racial hostility. Their very continued existence 
in America, and the continuance of the free immigration that allowed their family members to join them, depended upon their ability to prove that they could abandon their culture and adopt another, as quickly as possible. Slovaks may have come to view the passing on of culture as a burden to their children.

Finally, a Slovak immigrant might not have had a large enough group of other Slovaks with whom to carry on his customs. Even when Slovaks did form a critical mass, they might not have taken the opportunity to formally organize, trained, as they were in the Old Country, in atomization (Alexander 1987, 18, 21). Too, many in America could not afford the time or dues such formal organization demanded.

\section{Discussion of Interview}

My formal interview with Mrs. Pauline Goska provides support for these hypotheses. Mrs. Goska's peculiar use of pronouns betrays her deracination, a topic she had previously never discussed with me, her daughter. Too, I believe that Mrs. Goska's insecurity when discussing traditional Slovak folk culture reveals her awareness of the low esteem in which her natal culture is viewed in the United States. Deracination and the lingering wounds of racism contributed, I will argue, to Mrs. Goska's creation of silence within herself, and between herself and her children.

In transcribing the interview, I was struck immediately and hard by Mrs. Goska's use of pronouns. When I ask her about life in Slovakia, I use the pronoun "you." In using the pronoun "you," I was placing Mrs. Goska as a member of an ethnic and cultural group called "Slovaks." In Mrs. Goska's replies to my questions, she uses the pronoun "they." For example, in defining the word "komora," a room to be found in the very house Mrs. Goska was born and grew up in, she uses, not the pronoun "we," but, rather, "they." She reports, "That's where they put all their yearly produce. Their potatoes and their wheat and their rye. All the yearly produce for the winter that they had. Uh - the sugar beets." When asked how the room was kept safe from vermin, she replies, "I guess they knew - my grandfather knew how to do it. The women out there knew how to do all this and the room was tight. It was kept closed. There were no windows and there was no problem." I ask, "Did they maybe use some sort of herbs or 
something that kept bugs away?" And she replies, "Probably, but I don't know."

Later, when asked where pork was cured, Mrs. Goska replies, "They all knew how to smoke their meat. Cause they kept pigs for their own purpose and they killed them and they smoked them." When I ask, "And do you know what kind of wood they used to smoke them?" She replies, "No." "They" was used in a description of the home production of clothing:

MRS. GOSKA: Material was made by hand. They had looms to make their own material.

DVG: What kind? Wool? From sheep?

MRS. GOSKA: Flax. And some wool.

DVG: So what percentage of the clothes that people wore was store bought and what percentage was homeMRS. GOSKA: Very little was store bought. Even my underpants ... my mother used to make my underpants and put lace on them ...

DVG: Where was this material made? Was it made at home or in a central -

MRS. GOSKA: Home.

DVG: So everybody had a loom?

MRS. GOSKA: They had looms. Yeah. And they made their material for their tablecloths. That's why a tablecloth from those days is a treasure. Because it's handloomed. It lasts forever. And they grew what they needed to grow to make the material.

Mrs. Goska describes vivid memories of religious retreats:

We [she and her grandmother] used to go on retreats where the oxen would pull the wagons with the flowers and the blessed mother and she would dress me up in my finest with big ribbons in my hair and I would be the flower girl. She always said I was the prettiest girl in the village and she kept pushing me forward ...

These memories are some of her "earliest ... and my dearest" memories. She reports the lifelong impact these retreats had on her, "Like my brother Joe said, cause I'm a superstitious Slovak Catholic that I will never change from what I am. My memories of all my holidays and processions that I went on." Even so, "they" was used to describe these retreats:

DVG: And, um, where would you go for religious 
retreats? What was the -

MRS. GOSKA: That was called a 'pút'.' I don't remember. It was like in the hills somewhere. They had a chapel. I don't exactly remember where. What town. But they had different chapels and different places.

"They" is used to sum up the Slovak national character and others' stereotypes of Slovaks, "Uh, the Slovaks are a very joyous people. The Czechs consider them not so intelligent because they were a joyous, happy bunch of people. And, uh, I'm sure that they must have had festivals all the time."

Even now, after conducting this interview with my mother and transcribing it, these passages strike me with their strangeness. I am very used to Mrs. Goska considering herself, and calling herself at every opportunity, a Slovak. In fact, at one point in the interview, she uses the present perfect tense to refer to the population of Kovarce as if she still lived there, "We've had several Jewish families." Use of distancing third person pronouns seems especially strange given that Mrs. Goska assesses Slovak culture highly, "Culture in Czechoslovakia is so much better [than culture in America]." This better culture is one that should be clung to, she announces, "I think you should hang on to your heritage."

In one instance, I ask about, and Mrs. Coska explains, a difference between the groups identified as "they" and herself. Here it is clear that a Slovak cultural norm separated children and adults by dress:

DVG: And what did these women wear?

MRS. GOSKA: Oh, the - strictly the Slovak costumes.

The long black skirts, the black blouses and the babushkas on their heads ...

DVG: And how about for holidays?

MRS. GOSKA: It was a festive occasion. They had beautiful embroidered costumes and they would put them on ...

DVG: And did you wear those embroidered costumes, too?

MRS. GOSKA: No.

DVG: Why not?

MRS. GOSKA: Because we just wore dresses. The little children just wore regular type dresses that my mother made. My mother was an excellent seamstress ... Unless 
they grew older and were in processions in the church or some weddings and they would have costumes for them all embroidered. Hand embroidered. Everything was done by hand.

In other places where Slovaks are identified as "they," Mrs. Goska offers no such explanation, and, in fact, no such explanation would make sense. I would argue that where Mrs. Goska refers to Slovaks as "they," she is referring to skills and folkways that she attributes to Slovaks. These skills and folkways include: the construction of a komora, or storeroom, and the storing of home- and family-grown agricultural products in it; the tightening of the komora against vermin; the raising of pigs and smoking of meat; the home- and family-production of wool and flax; the hand looming of cloth; numerous colorful village-wide festivals and religious feasts. In these activities, Slovaks, she says, could express themselves as a "joyous, happy bunch of people." Why, then, does she use a pronoun that distances herself from these positively assessed folkways, in all of which she and her age peers, including her brother, participated?

Perhaps at least part of the answer lies in Mrs. Goska's lack of initiation in these activities, her deracination from this folk culture. As a child, she took part in these folkways; as an adult, she could not recreate them. She cannot, as she mournfully admits, make cloth; she does not know what kind of wood is good for smoking meat; she cannot do many of the things her own mother could do. She positively assesses the self-sufficiency these skills brought the Slovaks, and makes clear that she regrets this loss of cultural knowledge.

They were very self-sufficient. Plenty to eat and what they could store. They had no freezers so they couldn't store meat so they smoked it or canned it. My mother was an expert at canning. Even when she came to America. She used to buy uh pork and can it. She used to can pork. She used to can beef. All this stuff. I really don't know how to do. She would can everything. Can beans - everything ... My father built his house ... I guess his brothers must have helped him. I don't remember. But he built the house for us, and my grandfather built his own house. Uh. There is no such a thing as carpenters over there, and - same as today! If your 
car breaks down you, uh, my uncle had this old car and, uh, when his car broke down he had to make his own part ... And fix it himself. There is no such a thing as running to the garage around the corner or calling a repairman. You have to be your own repairman.

Her mother was multi-skilled and hard working. In this, she expressed her excellence. "She had to work and work. She worked in the fields. She worked in the priest's house. She cooked over there. She was an excellent cook. An excellent seamstress. She excelled at anything she had to do." Her grandmother, like other women in the village, could heal without recourse to a doctor.

She didn't need a doctor. My father used to tell us about the big tumor he had on his neck. My grandmother got some opium, that she made, her own, from the poppies, she gave it to him. She cut the tumor, and, it was like a boil. No problem. It was a boil. She slit it, drained it; it was fine. And he said, uh, 1 always had to laugh cause he'd say, 'It's a good thing she no kill me! My sister tell me I cry and cry when I was a baby. She gave me some of that opium and I sleep for three days ...' All the old women in Europe knew herbal medicines, and very seldom did you go to a doctor ... They grew them. Now how did she learn how to make opium out of poppies? She knew. They all knew. All the old women. I don't think my mother knew. But they did. They would dry the herbs in the povala - in the attic - in the povala.

At eight years old, Mrs. Goska left Slovakia. She was too young to be trained in the stuff of her "earliest ... my dearest memories." Her youth was not the only factor keeping Mrs. Goska from being initiated into her own, beloved culture. The desperation of her family's circumstances also contributed. Twice, when prodded about the passing on of family history and language skills, Mrs. Goska identifies her mother's heavy work load and poverty as forces that mitigated against such sharing, "My mother had enough trouble trying to make a living," and, "Once we came to America all she had to do was hustle for a buck."

Even if Mrs. Goska had been fully initiated into the culture she was born into, the desperation of her situation, like that of so many other Slavic immigrants in America, would have offered her no opportunity to learn and exercise cultural skills Slovaks 
had perfected over centuries. These skills required houses with enough room for looms, land, livestock, and access to natural products like hemp and flax. Even something so simple as singing was tied to practices that didn't exist for Slovaks in industrial America. As Mrs. Goska noted, "The singers in the fields ... sing about what they're doing. Like, if they're, uh, pulling the sugar beets they're singing about that." In America, Mrs. Goska's family had no land; not even the coal shaft in which her father toiled was theirs to claim. Too, there were few other Slovaks with whom to congregate. Mrs. Goska betrayed no knowledge of the larger forces at work to atomize the New Immigrants, but she did mention how small the Slovak community was, in comparison to the Irish and Welsh. She described how the Slovaks did carry on some traditions for a time.

They always got together for big sing-alongs, and telling stories, always. The food would be cooked, the stuffed cabbage and the kielbasi, and they would come over. Cause we used to have big rooms. Not like here. Big kitchens. And Joe and I would be sitting on the steps and listen to these scary stories they would tell. They used to have wonderful times.

These did not last, however. Forces connected with immigration ended them. Lives were constantly disrupted, communities scattered, by poverty. Mrs. Goska had to leave school and go to work for a wealthy Jewish family in New York. There she had to learn kosher cooking and Yiddish. Too, Slovaks were living in the worst areas, doing the worst work. Some, like her father, moved to escape the constant threat of black lung:

She [Mrs. Goska's mother] didn't want him to work in the coal mines anymore. So, she - I was working in New York, so she said would I come home and take care of the kids because Apa's ${ }^{1}$ getting worse. He's gonna get - you know - like his friends were dying from the lung - black lung? And she didn't want him to get worse so I came home and I took over and she went out to Bayonne.

Others also moved in search of work:

Pennsylvania became a very poor state. The mines were dying and people were leaving. They were - the Jamriks moved to Philadelphia, a city, where they could get 
work. Their children grew up and they got jobs in the cities. The Shuchters - the old people died, and their children moved to cities. Everybody moved. We moved to New Jersey because there was work here. But you move too far away from your families. So you just didn't get together any more. You had to have a large house to get together.

Here and in the reference above to big rooms, Mrs. Goska notes the importance of architecture in the passing on of cultural forms. In Kovarce, there was a communal hall used by the whole village, "It was just a place where a huge amount of people could go and have a wonderful time dancing. I told you, they were very joyous people. The slivovica would flow like water."

Finally, Mrs. Goska and others like her faced hostility, ridicule, and shame. She tells stories of being tricked, laughed at and placed in the wrong grade when she first went to school in America, and of developing a debilitating stutter. This must have been especially painful for her, because in Slovakia she loved school and got the highest possible grades. Education was stressed in her family:

[In Kovarce] I got a report card. I was very smart. I got ones in everything, and one was the highest mark you could get. And my mother was very careful that I had a good report card. As I said, she was all for learning. My mother had a way of saying that if you carry it on your in your head, it's not heavy, but if you carry it your load on your shoulders, that's when it's heavy. So, in other words, be smart. Learn as much as you can.

Not only American racism made this New Immigrant uncomfortable in school. Accused of a wrong she didn't commit by American classmates, unable to speak English or understand what was transpiring, she had to stay after school, and was later hit by her mother. The teacher responsible for the false accusation was a Slovak nun who could have cleared things up at any time by speaking Slovak to Mrs. Goska. Mrs. Goska attributes the woman's behavior to her own perverse personality. I wonder, though, if Sister Pauline, who shares a first name with Mrs. Goska, wasn't hiding her own shame or trying to communicate to her little immigrant student that America was a harsh world where every second spent being a Slovak, and not an American, would 
cost her.

During the New Immigration, America was technologically advanced, but lacked the multicultural sophistication it has today. Today Hmong embroideries adorn the homes of the best and the brightest, folk tales are appreciated for their deep truths, and folk technologies for their ingenuity. As mentioned above, though, when Mrs. Goska arrived in this country, peasant immigrants' folk culture was seen as proof of their racial inferiority. Mrs. Goska might have been uncomfortable about the kind of beliefs she describes below.

Well, like my mother told me after I had the baby. 'You do not go out until after you're churched. You do not leave the house' ... Because she knew of several women in the village that weren't churched. And she said, 'Somebody's gonna call you out. Now, if you hear somebody call you, [singsong] "Pavlina, Pavlina, " don't go out, cause they'll never see you again.'

If you go over the bridge at night - he'll drag you in! ... Yeah! Hastrman ${ }^{2}$ tam býva pod mostom. Under the bridge he lives in there and if you go over it at a certain time at night he'll drag you in and they'll never see you again. And, uh, when they're going through the fields there are different witches. How they have different kind of ceremonies. Bosorki. 'Bosorka' is 'witch.' Ona je bosorka. They had a lot of witch stories ... 'Yeah, I was going home - and - uh oh.' The bosorka would come and drain all the milk from the cows. That's why the cow was dry.

Mrs. Goska expressed her view of these aspects of Slovak culture. "Well, of course, when I was a kid, I believed her, but it's all superstition as far as I'm concerned" and, "You don't believe that, do you?" In her asking me this rhetorical question, I felt that my mother was communicating to me, "It's not actually true; we shouldn't believe it; so it has no value at all."

Immediately assuming the benefits of American culture was not a ready option. Mrs. Goska tells two stories of awkward attempts to learn "English - American - customs": an aborted and misunderstood version of what a "vacation" is that ended in embarrassment for the vacationers, and efforts to find and taste American food, which included eating discarded peanut butter 
in a garbage dump. In a nother anecdote, Mrs. Goska reports how inaccessible even the most common joys of American culture were to her. She enjoyed school sports, but she had to quit school to earn money to feed the family. In America, celebration was bought with money, not sweat or community. And there was no money to be had.

There was a magician in school and he cost ten cents to go see. My mother didn't have the ten cents to give me. She could not scrape up ten pennies. So I remember the insurance man was sitting there and he wanted to give me the ten cents. And my mother says, 'Ne. You cannot take it from anybody.' So I didn't see the magician.

This lack of access to American culture, exacerbated by her poverty and constant struggle for mere subsistence, extended to the birth of her children:

We got an apartment in Newark. We had to share a bathroom with a Jewish lady and her two sons. It was a cold-water flat. It wasn't easy. Like I tell Antoinette [her daughter\}, she keeps asking me, with her little baby, 'What did I do when I was that old? How old were we when we did this?' I said, 'How do I remember? I raised six kids in ten years. I don't remember what you people did. I just did the best I knew how. I didn't keep no baby books, saying, 'She started to talk; she started to walk.' You walked when you were ready to walk. You talked when you were ready to talk. My job was to make sure you were clean and well fed and had a place to sleep and if I couldn't afford to buy clothes I made them. Antoinette needed a coat when she was little. I didn't have money to buy one. I took one of my coats and made her a coat. Now I don't think I would know how to do it.

This, I think, is one of the traumata Mrs. Goska and other immigrants like her endured, a trauma that contributed to America's officially sanctioned view that she and others like her had no culture and were incapable of achieving the same cultural level as Americans. She was a rural peasant who immigrated to industrial company towns. That process robbed her of her birthright - traditional Slovak culture - that had given its practitioners beauty, expression, and a sense of belonging and pride. Its disappearance left a void, for access to the fruits of American culture was difficult 
if not impossible. Since Americans are certainly "they," this process helped doom my mother to a marginal status where she could not thrive as either Slovak or American. It, I suspect, also wounded her so deeply that, outside of this interview, it has been very difficult for me to get information from my mother about her life. I think it is just too difficult for her to talk about.

I came across an anomaly that threatened this hypothesis. I will argue here, though, that this anomaly ultimately supports the hypothesis. At one point Mrs. Goska did use first person pronouns when discussing Slovaks. In describing Slovak foodways, Mrs. Goska repeats the words "that was ours," over and over again; the phrase is spoken with increasing volume and falls with a mantric thud.

My mother would make the koláce from the poppy seed. That was ours. Koláce from the walnuts, that was ours, and kapušniki from the cabbage ... Same thing like the walnuts, only you'd put sweetened cabbage inside, and cheese. We had all those koláces. Then we had the soups. We had our own mushrooms ... Cause my father - my grandfather - would go out to get mushrooms in the fields. We always had dried mushrooms. And, uh, cabbage. Sauerkraut soups with the mushrooms. And that was ours. We had chick pea soup - that was ours. We raised our own. Everything was your own food that you raised. Or the walnuts. My grandfather had beautiful walnut trees. And the poppies, of course, we had our own seeds.

Here Mrs. Goska's use of the first person plural pronoun, and the repeated phrase "that was ours", is spoken in reference to a body of ritual behavior in which she has continuously participated, and competently: that of preparing food for the Christmas Eve feast. In fact, she has inculcated at least one of her children - me - in the preparation of all of these foods. Too, just as in the old country, the man of the family - my father - was responsible for gathering the wild mushrooms that would stud the sauerkraut soup. "They" is not used. Mrs. Goska can claim this memory, not only as something beautiful and cherished but painful for its irrevocable loss, but as something she can recreate, participate in, and teach to her children. Too, unlike sheepskin garments or other more public forms of a despised folk culture, foods could be 
enjoyed at home, far from racism's disparaging eyes.

There was another odd use of language in the interview: the extent to which my mother was translating as she spoke to me. I do the same thing, of course; when I ask her about her punishing but somehow rewarding childhood game of running barefoot over stubble in post-harvest grain fields, I do not use the word "stubble." This is because I am - foolishly - unsure that my mother will know the word "stubble." My mother was doing the same thing to me, but with much more fluidity. I stumbled before saying, in place of "stubble," "cut wheat;" she did not stumble at all before even so refined a translation as referring to her next door neighbor Kunko, who saved her life, as "Cohen," an Americanized version of the Slovak "Kunko."

I grew up in a house where I heard her speak Slovak daily, to my father or to other relatives, yet my mother rarely used Slovak in this interview about herself as a Slovak and Slovakia. In the twenty-thousand-word interview, Mrs. Goska uses Slovak words only fifteen times. These Slovak words may be produced in response from prodding from me, for example, "komora." At first my mother uses the English "keeping room." On one occasion she corrects my Americanized plural of the Slovak word "grof"3 to "grofs." "Crofi," she says. Isolated words are used to describe a feature of Slovak life; these are immediately translated. Examples: "povala," and "bosorka." Some words are widely used as-is by American Slavs from various countries, and not usually translated into English. Examples: "slivovica," "oplatki,"5 and "koláce." ${ }^{6}$ At two points I get the impression that Mrs. Goska has slipped into Slovak in order to rouse her memory, as when she says "Ona je bosorka," meaning, "She is a witch." A song is mentioned and the brief snippet of it that she recites is immediately translated. Only the one Slovak word "teacher" in "Pán Ucitel'," "Mister Teacher," is allowed to stand without translation or other justification.

A Russian writer on language and literature, Mikhail Mikhailovich Bakhtin (1895-1975), theorized that people usually maintain the integrity of the contents of their quotes, even to the extent of code-switching, if necessary, in order to do so (Moore 1993, 214, 236). If this theory is true, Mrs. Goska is an exception. She repeatedly puts English words into the mouths of Slovak characters who are well known to both of us. She does retain the ritual language of the Slovak Christmas Eve celebration, and, 
at one point, she puts Slovak words in her mother's mouth, "Č ty robiss?" immediately, though, providing the English translation, "What are you doing?"

Many explanations are possible for Mrs. Goska's thorough translation of remembered Slovak words into English. She may have been speaking to me not as her daughter, but as an American interviewer who was recording a semi-permanent version of her story. For the American, for the record, she would display her ability to do it right. The first Slovak word in the interview appears in a tense, guarded performance:

DVG: You had a house with how many rooms?

MRS. GOSKA: Uh, well, there was the keeping room.

DVG: Keeping room?

MRS. GOSKA: Keeping room.

DVG: What was that? Is that from Slovak?

MRS. GOSKA: That was a cold that was a room shut off from the rest of the house.

DVG: How do you say that in Slovak? Do you remember?

MRS. GOSKA: Komora. K-o-m-o-r-a. Komora.

Here "komora" is repeated and spelled out as if Mrs. Goska were engaging in the kind of rigid, unnatural, and temporary performance required at a spelling bee. Of course, even outside of the interview context, I am the American, the outsider. I cannot help but feel sad that for my mother, doing it right means filtering, so finely, invisibly, and automatically, her native speech out of dialogue with me. I think of the kinds of pressures that drilled into Mrs. Goska that her own ethnicity is something to be kept from Americans. Translation can be an open door, a way of working to invite in, to make comfortable, guests with whom you want to share your world. Translation can also be a way to shut out, to hermetically seal from expected ridicule and debasement what one holds most dear, and most unsharable.

One day my sister was in the shower. Her baby was crying. We had to endure frantic tears until my sister was available. My mother crouched down. She grabbed the baby's ams and swung them. "Mommy's coming with a big bag of milk!" And suddenly, she began to sing a Slovak folksong. My mother's hard life is reflected in her face, but suddenly this was another face, rosy, flexible, sparkling. The face of a "happy, joyous" person. I 
felt nailed to the floor. Truly, my mother contains another person, whom I don't know.

Another Eastern European woman who came to America early in the twentieth century celebrated her transformation thus:

I am just as much out of the way as if I were dead, for I am absolutely other than the person whose story I have to tell. Physical continuity with my earlier self is no disadvantage. I could speak in the third person and not feel that I was masquerading. I can analyze my subject, I can reveal everything, for she, and not $\mathrm{I}$, is my real heroine. My life I have still to live; her life ended when mine began (Antin, quoted in Zaborowska 1995, 39).

For me, such a transformation is no cause for celebration.

\section{Notes}

' Hungarian for "father."

${ }^{2}$ A hastrman is a supernatural creature that lives in water and can cause trouble for human beings. Mrs. Goska provides a translation for the rest of the sentence in her following English sentence.

${ }^{3}$ Grof - Count.

${ }^{4}$ Slivovica is a strong, clear alcoholic drink made from plums.

${ }^{5}$ Oplatki are rectangular, greeting-card-sized pieces of the same wheaten material used to make communion wafers. Bas-relief Christmas scenes are stamped into them. Slavic-Americans share their consumption with loved ones at Christmastime.

${ }^{6}$ Kolace are pastries. A filling, typically of ground, sweetened poppy seeds or ground, sweetened walnuts, is wrapped in a spiral of pastry dough and baked.

\section{List of Works Cited}

Alexander, June Granatir. 1987. The Immigrant Church and Community: Pittsburgh's Slovak Catholics and Lutherans, 1880-1915. Pittsburgh: University of Pittsburgh Press.

Bell, Thomas. 1976 [1941]. Out of This Furnace. Pittsburgh: University of Pittsburgh Press. 


\section{Ethnlc Studles Revlew Volume 29}

Boas, Franz. 1938. Mind of Primitive Man. New York: MacMillan.

Bukowczyk, John. 1987. And My Children Did Not Know Me. Bloomington: Incliana University Press.

Ference, Gregory C. 1995. Sixteen Months of Indecision: Slovak American Viewpoints toward Compatriots and the Homeland from 1914 to 1915 as Viewed by the Slovak Language Press in Pennsylvania. Selingsgrove: Susquehanna University Press.

Goska, Danusha V. 2002. "Silence" TheScreamOnline.

Grant, Maclison. 1916. The Passing of the Great Race or The Racial Basis of European History. New York: Scribner's.

Hammerova, Louise B. and lvor Ripka. 1994. Speech of American Slovaks. Jazykove Prejavy Americkych Slovakov. Bratislava: VEDA.

Hasek, Jaroslav. 1973 [1921-1923]. The Good Soldier Svejk. A new and unabriclged translation by Cecil Parrott, with the original illus. by Josef Lada. New York: Crowell.

Higham, John. 1967. Strangers in the Land. Patterns of American Nativism 1860-1925. New York: Atheneum.

Hyatt, Marshall. 1990. Franz Boas Social Activist. The Dynamics of Ethnicity. New York: Greenwood Press.

Ledbetter, Eleanor E. 1918. The Slovaks of Cleveland. With Some General Information of the Race. Cleveland: Cleveland Americanization Committee.

Leighton, Etta V. 1922. "Our Immigration Problem." Current History April, 115-117.

Lodge, Henry Cabot. 1891. "The Restriction of Immigration." North American Review. January: 30-32.

Lucy, John. 1993. Reflexive Language, Reported Speech and Metapragmatics. Cambriclge: Cambriclge University Press.

Moore, Robert E. 1993. "Performance Form and the Voices of Characters in Five Versions of the Wasco Coyote Cycle," pp. 213-240 in Lucy. 


\section{Goska-No Opportunity for Song}

Novak, Michael. 1971. The Rise of the Unmeltable Ethnics. New York: MacMillan.

Ribčanská, Eva. 1998. "Contemporary Ethnicity, Maintenance of Ethnic Culture and Ethnic Change: The Case of the Slovak Americans in Western Pennsylvania." Human Affairs VIII: 1: 68-84.

Roberts, Kenneth L. 1920. "Handing it Back." Saturday Evening Post, 192: 8-9 May 29.

Seckar, Alvena. 1952. Zuska of the Burning Hills. New York: Oxford University Press.

Stasko, Jozef. 1974. Slovaks in the United States of America Ontario: Dobra Kniha.

Stein, Howard F. 1980. An Ethno-Historic Study of Slovak-American Identity. New York: Arno Press.

Stolarik, Marian Mark. 1985. Growing Up on the South Side. Three Generations of Slovaks in Bethlehem, Pennsy/vania, 1880-1976. Lewisburg: Bucknell University Press.

Stolarik, Marian Mark. 1989. Immigration and Urbanization: The Slovak Experience, 1870-1918. New York: AMS Press, Inc.

Warne, Frank Julian. 1913. The Immigrant Invasion. New York: Dodd, Mead.

Wtulich, Josephine. 1994. American X'enophobia and the Slav Immigrant: A Living Legacy of Mind and Spirit. New York: Eastern European Monograph Series, Boulder and Columbia University Press

Zaborowska, Magda. 1995. How We Found America. Reading Gender Through East European Immigrant Narratives. Chapel Hill: North Carolina Press. 